Article

\title{
Factors Affecting the Effectiveness of Bioelectrochemical System Applications: Data Synthesis and Meta-Analysis
}

\author{
Simeng $\mathrm{Li}^{*}$ (10) and Gang Chen \\ Department of Civil and Environmental Engineering, FAMU-FSU College of Engineering, \\ 2525 Pottsdamer Street, Tallahassee, FL 32310-6046, USA; gchen@eng.famu.fsu.edu \\ * Correspondence: sl16b@my.fsu.edu; Tel.: +1-850-645-0126
}

Received: 2 June 2018; Accepted: 6 July 2018; Published: 25 July 2018

\begin{abstract}
Microbial fuel cells (MFCs) and microbial electrolysis cells (MECs) are promising bioelectrochemical systems (BESs) for simultaneous wastewater treatment and energy/resource recovery. Unlike conventional fuel cells that are based on stable chemical reactions, these BESs are sensitive to environmental and operating conditions, such as temperature, $\mathrm{pH}$, external resistance, etc. Substrate type, electrode material, and reactor configuration are also important factors affecting power generation in MFCs and hydrogen production in MECs. In order to discuss the influence of these above factors on the performance of MFCs and MECs, this study analyzes published data via data synthesis and meta-analysis. The results revealed that domestic wastewater would be more suitable for treatment using MFCs or MECs, due to their lower toxicity for anode biofilms compared to swine wastewater and landfill leachate. The optimal temperature was $25-35{ }^{\circ} \mathrm{C}$, optimal $\mathrm{pH}$ was $6-7$, and optimal external resistance was 100-1000 $\Omega$. Although systems using carbon cloth as the electrodes demonstrated better performance (due to carbon cloth's large surface area for microbial growth), the high prices of this material and other existing carbonaceous materials make it inappropriate for practical applications. To scale up and commercialize MFCs and MECs in the future, enhanced system performance and stability are needed, and could be possibly achieved with improved system designs.
\end{abstract}

Keywords: bioelectrochemical system (BES); microbial fuel cell (MFC); microbial electrolysis cell (MEC); maximum power density; hydrogen production rate; COD removal; data synthesis; meta-analysis

\section{Introduction}

Bioelectrochemical systems (BESs) are emerging hybrid systems of biotechnology and electrochemistry that are able to sustainably generate chemical or electrical energy through redox reactions catalyzed by microorganisms [1]. Depending on the mode of applications (Figure 1), BESs can be divided into microbial fuel cells (MFCs), microbial electrolysis cells (MECs), microbial electrosynthesis (MESs), microbial desalination cells (MDCs), and microbial solar cells (MSCs), among which MFCs and MECs are the most studied in the recent years [2].

Like other types of electrochemical cells (e.g., batteries), both MFCs and MECs consist of two electrodes (i.e., an anode and a cathode) that are connected with a conductive wire to form a closed electrical circuit (Figure 1). When the redox potential of the cathode reduction half-reaction $\left(\mathrm{E}_{\mathrm{cat}}\right)$ is higher than that of the anode oxidation half-reaction $\left(E_{a n}\right)$, electricity is generated, due to a positive cell potential $\left(\mathrm{E}_{\mathrm{cell}}=\mathrm{E}_{\mathrm{cat}}-\mathrm{E}_{\mathrm{an}}\right)$. Otherwise, external power (i.e., electrolysis) is needed to propel the redox reactions. The biological and electrochemical processes in both types of BESs are uniquely 
linked by the electron exchange between the microorganisms and electrodes [1]. The electrons can be transferred (1) directly, via the outer membrane proteins (e.g., cytochromes) or conductive nanowires of the microorganisms; or (2) indirectly, through electron shuttles (e.g., flavins), when there is no physical interaction between the electrodes and microorganisms [3]. On the cathode side, the transferred electrons can be utilized to accomplish any reduction reactions, which lead to diverse application possibilities of BESs [2].
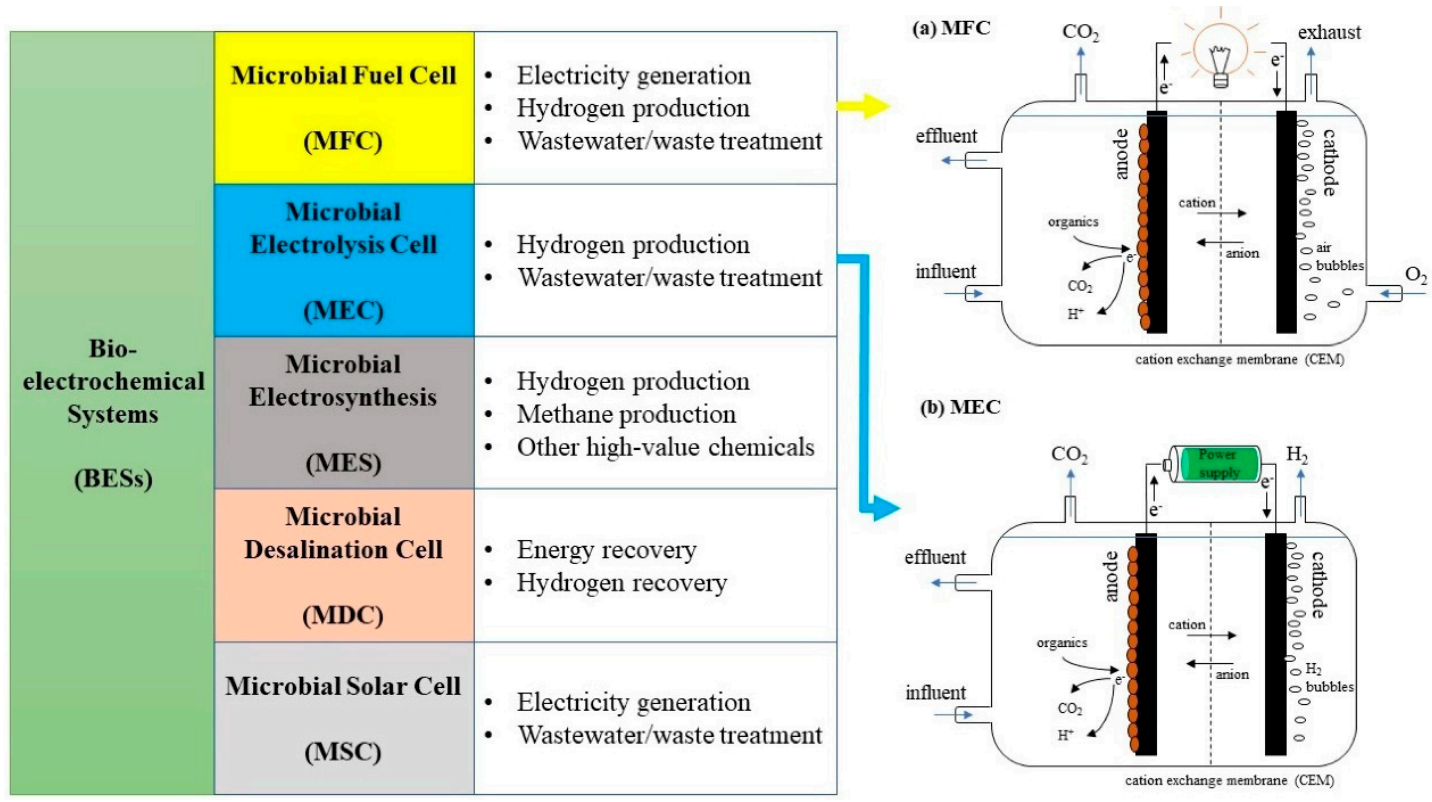

(b) MEC

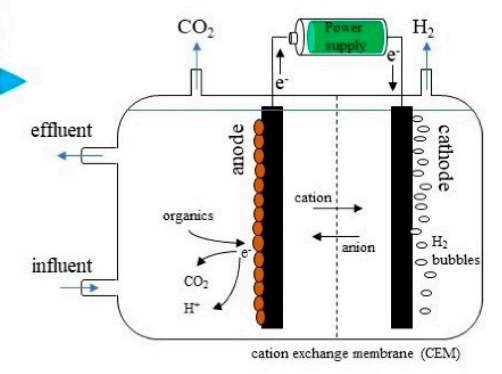

Figure 1. Overview of various types of bioelectrochemical systems (BESs), and schematics of the two most common BESs: (a) two-chamber microbial fuel cell (MFC); (b) two-chamber microbial electrolysis cell (MEC) for $\mathrm{H}_{2}$ production.

MFCs are capable of converting the chemical energy directly from a wide range of organic matter (e.g., wastewater and lignocellulosic biomass) to electrical energy, using exoelectrogens (e.g., Geobacter sulfurreducens and Shewanelle putrefaciens) at the anode [4]. The electrons collected at the anode flow through the external circuit to the cathode, where they combine with the protons and $\mathrm{O}_{2}$ to produce water. Thus, an electric current is formed, due to the flow of electrons, and the generated electricity can be directly utilized or stored. The most common designs of MFCs are two-chamber and single-chamber. Unlike the two-chamber MFC shown in Figure 1, a single-chamber MFC has only the anode chamber, which is wrapped by a chamber wall consisting of a waterproof cation exchange membrane and cathode material (e.g., carbon cloth) on the outer surface.

Inversely, MECs are able to generate chemical energy (e.g., $\mathrm{H}_{2}, \mathrm{CH}_{4}$, and other value-added chemicals) at the cathode, when an external input of electricity is applied to the circuit in order to overcome the thermodynamic barrier, and drive the flow of electrons released by the microorganisms at the anode [2]. Unlike an MFC, whose cathode chamber is generally oxygen-enriched, the cathode chamber of an MEC must be maintained as anaerobic (without $\mathrm{O}_{2}$ ) or anoxic (low $\mathrm{O}_{2}$ ), in order to facilitate the formation of desired products. For example, with high concentrations of $\mathrm{H}_{2}$ under anoxic conditions, $\mathrm{CH}_{4}$ can be produced with MECs at the presence of $\mathrm{CO}_{2}$ and methanogens. Single-chamber MECs can also function properly [5]. However, unlike single-chamber MFCs, in a single-chamber MEC, the anode and cathode are both inside a closed/semi-closed $\mathrm{O}_{2}$-limiting chamber. Notably, regardless of the reactor configurations, an MEC can be coupled with an MFC, which serves as an in-situ power supply for biohydrogen production from organic substrates (e.g., acetate) [6].

BESs have been investigated for their potential applications in various areas, especially wastewater treatment with simultaneous production of bioenergy and biopolymers $[7,8]$. Considerable removal of 
chemical oxygen demand (COD) using MFCs or MECs has been reported for the biological treatment of domestic wastewater [9], swine wastewater [10], brewery wastewater [11], landfill leachate [4], etc., along with the simultaneous benefits of energy generation and biohydrogen production that greatly help cut down the high costs of energy. However, the performance of these complex BESs, in terms of COD removal and energy /chemical production, is mutually affected by many factors, including the wastewater (substrate) type [12], electrode material [13], separator material [14], inoculum type [14], reactor configuration [15], mode of operation [16], etc. Although many laboratory experiments have shown the significant potentials of BESs, only a few pilot studies have been successfully operated in real-world conditions [17]. Identifying the affecting factors and understanding the impacts of these factors on the effectiveness of BESs are of essential importance for the optimization of these systems.

This work aimed to summarize and compare the effects of the major factors that have been reported to influence the performance of the major two types of BESs (i.e., MFCs and MECs). Under the influences of these factors, the effectiveness of the systems was evaluated in terms of both treatment and energy/biohydrogen production. Specifically, the treatment level was represented by the COD removal in an MFC or MEC, the energy production of an MFC was characterized by its maximum power density (i.e., maximum power per unit surface area of the anode, $\mathrm{mW} / \mathrm{m}^{2}$ ), while the biohydrogen generation of an MEC was assessed based on the hydrogen production rate (HPR; i.e., $\mathrm{H}_{2}$ produced per unit working volume per day, $\mathrm{m}^{3} \mathrm{H}_{2} / \mathrm{m}^{3} / \mathrm{d}$ ). A meta-analysis using statistical techniques to combine and analyze findings from multiple independent studies was performed in order to improve estimates of the sizes of the effects. The current barriers and future directions for commercial installations of the two types of BESs are also discussed at the end.

\section{Results and Discussion}

\subsection{Effects of Temperature on the Performance of Microbial Fuel Cells and Microbial Electrolysis Cells}

Like many other anaerobic reactors, MFCs and MECs are sensitive to temperature (Figure 2). The power generation in MFCs and the hydrogen production in MECs, as well as the COD removal in both types of reactors, varies drastically as the working temperature changes. In general, temperatures that are either too high (e.g., $>45^{\circ} \mathrm{C}$ ) or too low (e.g., $<15^{\circ} \mathrm{C}$ ) significantly hinder power generation in MFCs and hydrogen production in MECs, while temperatures between 30 and $40{ }^{\circ} \mathrm{C}$ seems to favor the performance of these reactors. At the same time, the highest COD removal in both MFCs and MECs has been found within the temperature range from 25 to $35^{\circ} \mathrm{C}$. In terms of the principle of economy, Tang et al. suggested the optimal operating temperature of MFC be $30^{\circ} \mathrm{C}$, even though the performance at $35^{\circ} \mathrm{C}$ slightly improved [18]. According to the fitted results, the optimal operating temperature of MECs was very close to that of MFCs, indicating the feasibility of integrating these two types of reactors under the same operating temperature.

The impacts of temperature are attributed to the different resulting microbial activities [15,19-21]. Studies have revealed the dominance of electrogenic bacteria (e.g., Geobacter sulfurreducens) [22] and better growth and activity of electrochemically active biofilms [23] at the optimal temperatures near $30{ }^{\circ} \mathrm{C}$. The overall microbial activity decreases as the operating temperature becomes more extreme, which in turn slows down the microbial generation of electrons and protons [15]. One encouraging fact is that the changes of power generation in MFCs and hydrogen production in MECs are usually smaller than $10 \%$ when the operating temperature is between 20 to $35^{\circ} \mathrm{C}[15,24,25]$, indicating that these reactors could tolerate temperature changes over a wide range of temperatures in real-world applications for wastewater treatment. Heidrich et al. speculated that the biofilms attached to the electrodes possessed self-heating effects that allowed them to adapt to sub-optimal temperatures [24]. It should be noted that the optimal temperatures for power generation and hydrogen production are different from the optimal temperatures for COD removal, possibly because the microbial species most effective in utilizing the biodegradable organics are oftentimes different from electrochemically active species [3]. 

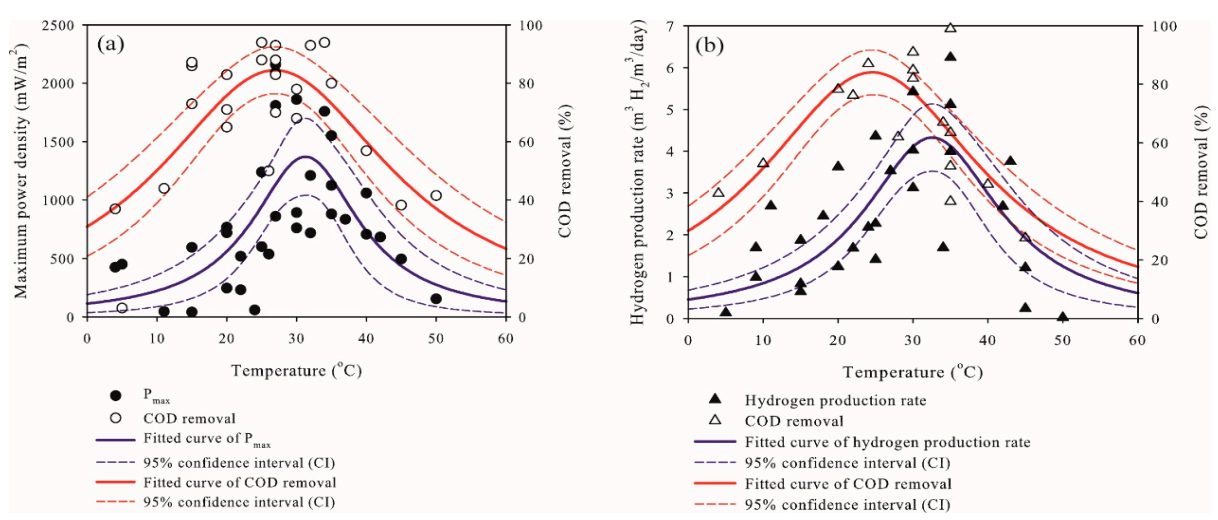

Figure 2. Influences of temperature on (a) MFCs' power generation and chemical oxygen demand (COD) removal and (b) MECs' hydrogen production and COD removal.

\subsection{Effects of $\mathrm{pH}$ on the Performance of Microbial Fuel Cells and Microbial Electrolysis Cells}

The anode $\mathrm{pH}$ also greatly affects the performance of MFCs and MECs (Figure 3). A pH between 6.5 and 7.5 correlates with relatively higher power densities, up to over $1200 \mathrm{~mW} / \mathrm{m}^{2}$, whereas a $\mathrm{pH}$ between 5 and 6 derives a more significant hydrogen production rate, as high as about $8 \mathrm{~m}^{3}$ $\mathrm{H}_{2} / \mathrm{m}^{3} / \mathrm{d}$. The impacts of $\mathrm{pH}$ on the COD removal in both types of reactors are also pronounced. The COD removal at the optimal $\mathrm{pH}$ ranges is nearly three times higher than that at extremely low or high $\mathrm{pH}$ ranges. These results reflect that the microbial activities in MFCs, and MECs are slower at a sub-optimal $\mathrm{pH}$ than at the optimal $\mathrm{pH}$. The low values for both power generation in MFCs and hydrogen production in MECs at high $\mathrm{pH}(>10)$ might be due to the poor proton transfer, as the proton concentration gradient across the proton exchange membrane (PEM) decreased [26]. Proton transfer is known as a rate-limiting factor for both types of reactors [27]. At a relatively low $\mathrm{pH}$, the proton concentration gradient accelerates the proton transfer, which increases the proton availability in the cathode chamber for biohydrogen production. This would explain why the relatively lower $\mathrm{pH}$ is preferred for hydrogen production in MECs. However, the reactor performance deteriorates as the $\mathrm{pH}$ decreases to below 3, as the acidic environment becomes no longer suitable for the growth of most electrogenic microbes [28]. Nevertheless, certain species have been reported to function well in MFCs even at such severe low- $\mathrm{pH}$ conditions, generating power densities ranging from 20 to $55 \mathrm{~mW} / \mathrm{m}^{2}$ using single-chamber, air-cathode, tubular MFCs [29]. Comparing to MFCs, the performance of MECs are more vulnerable to the increase of $\mathrm{pH}$, because the production of biohydrogen would not occur without the presence of a proton in the cathode chamber.
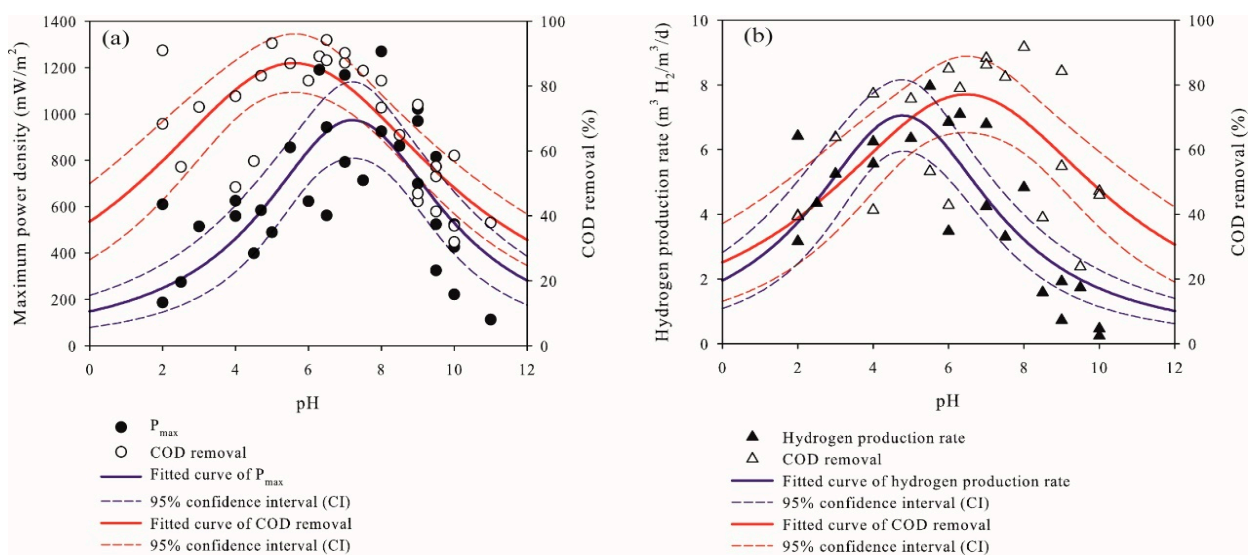

Figure 3. Influences of $\mathrm{pH}$ on (a) MFCs' power generation and COD removal and (b) MECs' hydrogen production and COD removal. 


\subsection{Effects of External Resistance on the Performance of Microbial Fuel Cells and Microbial Electrolysis Cells}

External resistance $\left(\mathrm{R}_{\mathrm{ext}}\right)$ affects the performance of MFCs and MECs, by limiting the flow of electrons form the anode to the cathode [30]. According to Ohm's Law $\left(V=I R_{\text {ext }}\right)$, both the potential (V) and the current (I) outputs would be influenced. Consequently, the power output (W) is also affected as shown by $\mathrm{W}=\mathrm{I}^{2} \mathrm{R}_{\text {ext. }}$. In MFCs and MECs, increased external resistance decreases the power density, as well as the treatment efficiency (Figure 4). Generally, the anode potential, which directly determines the anode availability as electron acceptors, is regulated by the external resistance [31]. As a result, the growth competition between the electrogenic and non-electrogenic microbial communities is influenced when different external resistances are applied to the circuits. Likewise, the growth competition among different electrogenic bacteria is also impacted, directly through the utilization of an anode or indirectly through the alteration of the microenvironmental conditions [30]. Eventually, the microbial community structures established under different external resistance would differ, thus affecting the consumption of organic substrates and the associated production of protons in the anode biofilm [32]. The accumulation of protons in the anode biofilm would lower the $\mathrm{pH}$, which again would affect the biofilm environment. The microbial community in the anode biofilm is most susceptible to the change of external resistance when the anode potential is low. Below anode potentials of approximately $-1.5 \mathrm{~V}$, the impacts on most identified Geobacter strains have been reported to be pronounced [32].
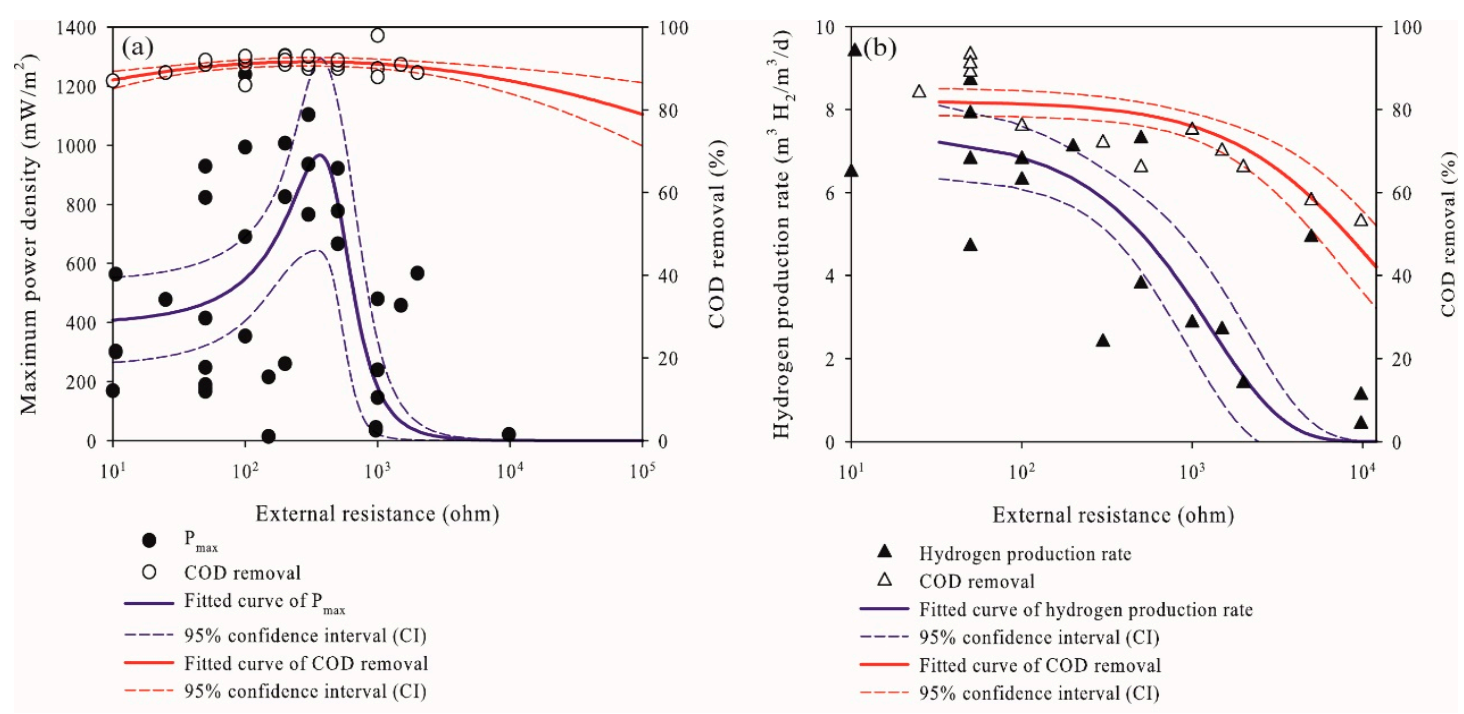

Figure 4. Influences of external resistance on (a) MFCs' power generation and COD removal and (b) MECs' hydrogen production and COD removal.

When the external resistance was either too low (e.g., $10 \Omega$ ) or too high (e.g., $10 \mathrm{k} \Omega$ ), power generation in MFCs became weak. At low resistance, the low redox potential at the anode probably made it unfavorable as an electron acceptor for the microbes; at high resistance, the resistance was maybe too high (almost mimics an open circuit) for the microbes to transfer their electrons. MFCs operating at optimal external resistance have been reported to have enhanced power generation, reduced methane production, and increased Coulombic efficiency [33]. However, low resistance would not hinder the electron transfer in an MEC, because the electrons are driven by the external power provided to the system.

\subsection{Effects of Substrate Type on the Performance of Microbial Fuel Cells and Microbial Electrolysis Cells}

Three major types of wastewater (i.e., domestic wastewater, swine wastewater, and landfill leachate) have often been used to feed MFCs and MECs while being treated or pretreated. The power 
generation in MFCs, the hydrogen production in MECs, and the treatment efficiency in both types of reactors were statistically analyzed and compared, as shown in Figure 5. From the comparison, it is apparent that domestic wastewater is the most suitable in terms of power generation in MFCs and hydrogen production in MECs, while the lowest power densities and hydrogen production rates have been found with MFCs and MECs using landfill leachate. Interestingly, as reflected by the COD removal, higher treatment efficiency has been shown in those reactors treating swine wastewater.

(a) MFC

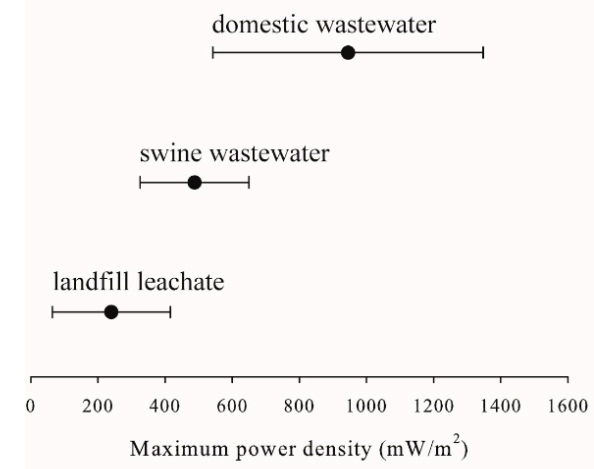

(b) MFC

domestic wastewater

swine wastewater
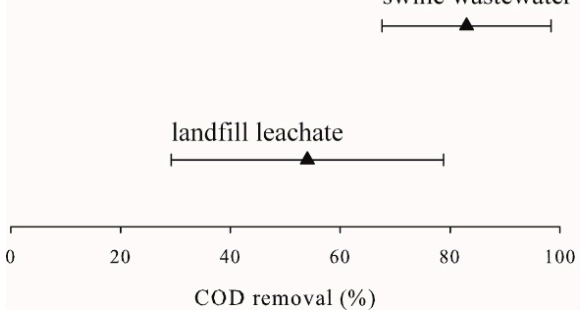

(c) MEC

\section{domestic wastewater}

swine wastewater

swine wastew

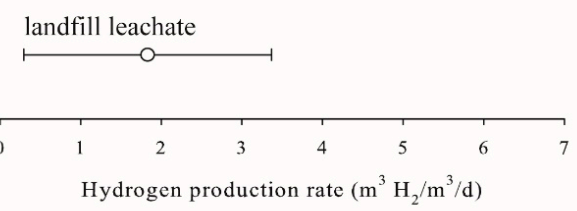

(d) MEC

domestic wastewater

swine wastewater

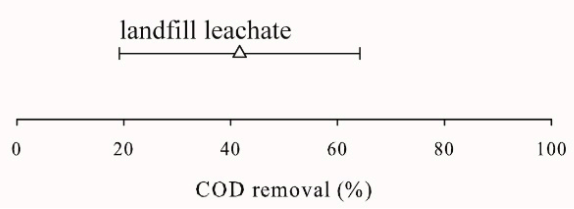

Figure 5. Influences of substrate type on (a) an MFCs' power generation; (b) an MFCs' COD removal; (c) an MECs' hydrogen production; and (d) MECs' COD removal.

The suitability of wastewater sources for MFCs and MECs mainly depends on the biodegradability of the containing substrates [24], but other characteristics of the wastewater, such as $\mathrm{pH}$, ionic strength, and toxicity, would also make a difference.

The influences of $\mathrm{pH}$ have been discussed earlier in this paper. A high ionic strength usually reduces the internal resistance, and results in a decrease of anode potential and an increase of cathode potential, giving a larger overall circuit voltage. Although swine wastewater and landfill leachate are rich in biodegradable organics and usually have high ionic strengths, the relatively high concentrations of toxic compounds like ammonium [34] and heavy metals [35] would negatively impact the microbial growth and eventually the reactor performance when these types of wastewater were used to feed MFCs and MECs.

\subsection{Effects of Electrode Type on the Performance of Microbial Fuel Cells and Microbial Electrolysis Cells}

Various types of electrode materials have been investigated and developed in the recent years to improve the performance of MFCs and MECs while reducing the cost of the reactors. In these BESs, the electrodes are not only conductors, but also habitats for electrogenic microbes. Therefore, good electrode materials should demonstrate some special surface characteristics, such as good 
biocompatibility, high specific surface area, considerable surface roughness, and the ability to efficiently transfer electrons between microbes and electrodes [36]. Considering these above characteristics, carbonaceous materials are often preferred as anode materials.

In the study, the three most commonly used carbonaceous electrode materials (i.e., carbon paper, carbon cloth, and graphite brush) were compared (Figure 6). Carbon paper is thin and firm yet slightly brittle, and is characterized by a relatively smooth surface. On the contrary, carbon cloth is more flexible and porous. Graphite brush is a fiber fabric, much thicker than the above two materials, and the brush configuration allows for more available surface area (although less than carbon cloth) for the attached growth of microbes. The statistical results demonstrate that electrodes made of carbon cloth are the best for both power generation in MFCs and hydrogen production in MECs. The performance of reactors using carbon paper as the electrodes is slightly better than that of reactors using graphite brush. The high specific surface areas of carbon cloth and carbon paper are believed to be the key to their greater power generation and COD removal. However, the high prices of these carbonaceous materials, especially carbon cloth (approximately $\$ 1000 / \mathrm{m}^{2}$ ) [37], are prohibitive for practical applications of these BESs. Another concern is the high electrical resistivity of these carbonaceous materials, which would lead to large electrode ohmic losses in large-scale systems [36].

(a) MFC

graphite fiber brush
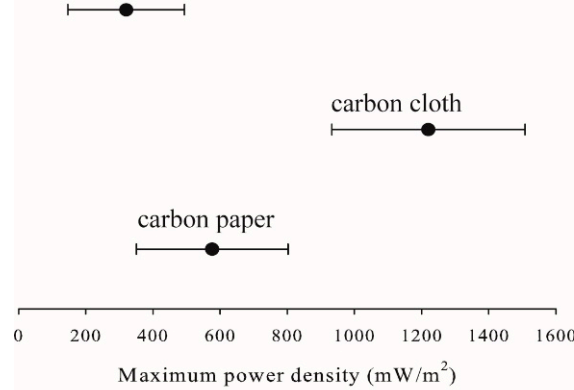

(b) MFC

graphite fiber brush

carbon cloth

carbon paper

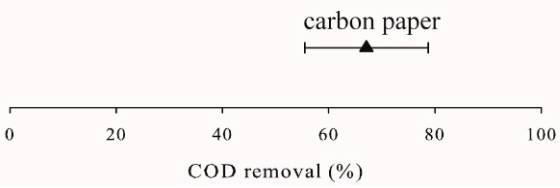

(c) MEC

graphite fiber brush

carbon cloth

carbon paper
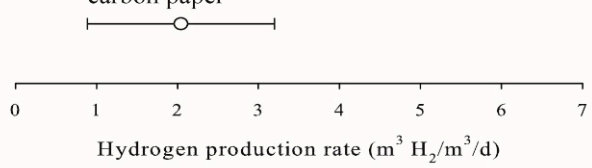

(d) MEC

graphite fiber brush

carbon cloth

carbon paper

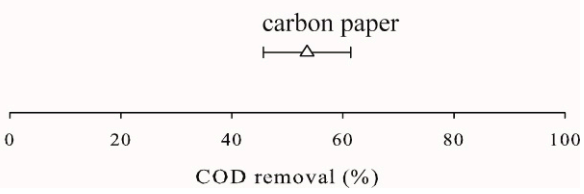

Figure 6. Influences of electrode material on (a) MFCs' power generation; (b) MFCs' COD removal; (c) MECs' hydrogen production; and (d) MECs' COD removal.

\subsection{Effects of Reactor Configuration on the Performance of Microbial Fuel Cells and Microbial Electrolysis Cells}

In order to optimize the performance of MFCs and MECs, a wide range of configurations have been designed and developed. The single-chamber design and the two-chamber design were compared in this study, while the performance of the scaled-up systems $(>1 \mathrm{~L})$ [17] was also discussed (Figure 7). The two-chamber systems are as shown in Figure 1, in which the proton would travel through the membrane and arrive at the cathode chamber to join further bioelectrochemical reactions. 
The single-chamber systems have only the anode chamber as the electron acceptor of the cathode, which is typically the oxygen in the air (a.k.a., an air-cathode). The results show that the two-chamber MFCs generally generate higher power, while the one-chamber MECs could produce more biohydrogen. However, the two-chamber systems are more problematic with their high electrical resistivity, which should result in relatively lower power generation in MFCs than the single-chamber designs [15]. In fact, two-chamber systems were more often used in existing studies because of their simplicity and stability. A great variety of substrates and operating conditions have been investigated using two-chamber systems, and oftentimes the substrates were readily biodegradable (e.g., acetate) and the conditions were optimal [38-41]. The preference of two-chamber systems in previous studies might have introduced biased results for the comparisons.

(a) MFC

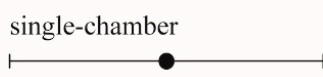

two-chamber

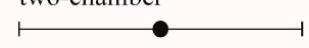

large-scale

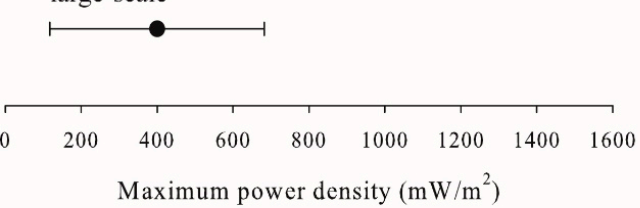

(b) MFC

single-chamber

two-chamber

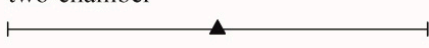

large-scale
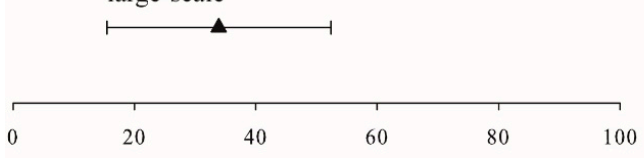

COD removal (\%)

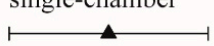

(c) MEC

single-chamber

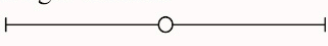

two-chamber

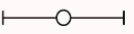

(d) MEC

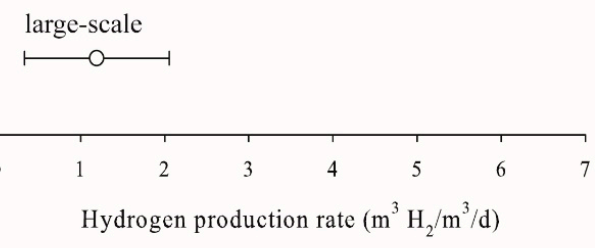

single-chamber

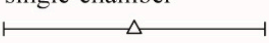

two-chamber
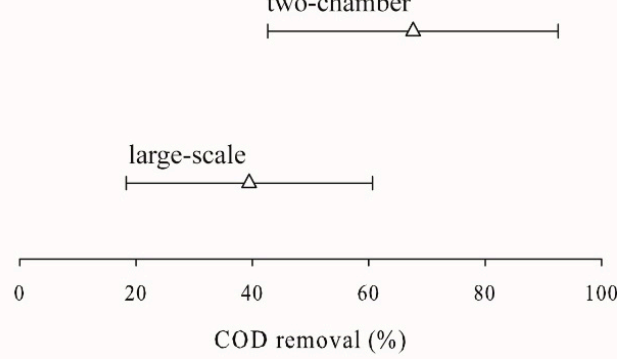

Figure 7. Influences of reactor configuration on (a) MFCs' power generation; (b) MFCs' COD removal; (c) MECs' hydrogen production; and (d) MECs' COD removal.

Notably, power generation in MFCs, hydrogen production in MECs, and COD removal in both systems were significantly lower when the reactors were scaled up. Larger systems are faced with more complex challenges, such as higher electrical resistivity and instability [42]. Although there were a few successful examples of pilot systems, the high cost is another issue that obstructs the real-world applications of these BESs. Novel configurations and cheaper electrode materials with larger surface areas must be further investigated, in order to cut down the expenses. 


\section{Implications for Commercial-Scale Applications}

MFCs and MECs are promising technologies for wastewater treatment and energy supply. The electricity generated in MFCs and the biohydrogen recovered in MECs could significantly reduce the economic burden to treat domestic and industrial wastewater, while providing safe water to the public. The real-world applications of these BESs must be scaled up and commercially profitable. Therefore, the two major challenges are (1) to optimize the system performance and (2) to lower the material costs.

The results presented in this study suggested that the optimal operating conditions are as follows: a temperature of $25-35{ }^{\circ} \mathrm{C}$, a pH of 6-7, and an external resistance of 100-1000 $\Omega$. Single-chamber systems would be more attractive, especially for MECs. Although it is possible to treat almost all types of organic-containing wastewater, some complex wastewater, such as landfill leachate, should be pretreated for detoxification. The electrode materials that are currently used are problematic, with either their high prices or low surface areas. Novel biocompatible electrodes should be the focus in future studies.

The performance and stability of the systems can also be improved with enhanced configurations. For wastewater treatment, multiple MFC or MEC units should be connected as stacks, in order to further increase their power generation, biohydrogen recovery, and treatment efficiency. However, the MFC and MEC stacks are plagued by low efficiency and instability, due to the nonlinear nature of the unit systems [43]. Unlike conventional fuel cell stacks, which are based on stable chemical reactions in each unit, the MFC and MEC units depends on relatively instable microbial activities for power and hydrogen outputs. The performance of each individual unit could be very sensitive to the environmental and operating conditions, which would result in even more pronounced fluctuation of the system outputs. In addition, the overall system efficiency is usually reduced because of the worst performing unit(s). To solve this issue, the output from each unit could be individually collected, and then combined in the desired ways with the use of an energy/resource-harvesting station. Recently, a multi-anode approach using segmented anode arrays has also been developed, in order to improve the performance of each MFC and MEC unit [44].

\section{Methods}

\subsection{Data Sources}

The Scopus database (Elsevier, New York, NY, United States) was used for an extensive literature search with the search terms "microbial fuel cell AND temperature", "microbial fuel cell AND pH", and "microbial fuel cell AND scale up". Similarly, the same search was performed for "microbial electrolysis cell". However, the search results needed to be carefully selected, because many of the studies were either unable to provide sufficient information or irrelevant. The same searches were also performed using Google Scholar and Web of Science, but no additional studies were found that were suitable for the data synthesis and meta-analysis in this paper. Studies with no quantitative results or measures of variance were excluded. The cut-off date for publications that were included in this meta-analysis was 15 May 2018. Consequently, a total of 108 studies on MFCs or MECs were used, as summarized in Table 1 . The relevant data were extracted directly or indirectly (DataThief III was used for the extraction when the data was presented graphically) from each study, and subsequently inserted into Excel for further processing.

Although independent studies were selected randomly for the data synthesis and meta-analysis, the results might have been affected due to the intrinsic publication bias, as studies with no significant effects were less likely to be considered for publication [45]. 
Table 1. Matrix of studies providing data for the data synthesis and meta-analysis.

\begin{tabular}{|c|c|c|c|}
\hline Groups & Subgroups & Number of Studies & References \\
\hline \multirow{3}{*}{ Temperature (Temp.) } & Low $\left(<25^{\circ} \mathrm{C}\right)$ & 13 & {$[15,19-21,24,46-53]$} \\
\hline & Moderate $\left(25-35^{\circ} \mathrm{C}\right)$ & 12 & {$[15,19,21,50,51,54-60]$} \\
\hline & $\operatorname{High}\left(>35^{\circ} \mathrm{C}\right)$ & 9 & {$[19,60-67]$} \\
\hline \multirow{3}{*}{$\mathrm{pH}$} & Low $(<6)$ & 5 & [68-72] \\
\hline & Moderate (6-8) & 6 & {$[5,61,73-76]$} \\
\hline & $\operatorname{High}(>8)$ & 5 & {$[73,77-80]$} \\
\hline \multirow{3}{*}{ External resistance $\left(\mathrm{R}_{\mathrm{ext}}\right)$} & Low $(<100 \Omega)$ & 7 & {$[30,50,81-85]$} \\
\hline & Moderate $(100-1000 \Omega)$ & 9 & {$[30,50,82-84,86-89]$} \\
\hline & $\operatorname{High}(>1000 \Omega)$ & 5 & {$[50,83,88,90,91]$} \\
\hline \multirow{3}{*}{ Substrate (S) } & Domestic wastewater & 10 & {$[20,21,49,79,92-97]$} \\
\hline & Swine wastewater & 7 & {$[10,41,98-102]$} \\
\hline & Landfill leachate & 8 & {$[4,103-109]$} \\
\hline \multirow{3}{*}{$\begin{array}{l}\text { Electrode material } \\
\text { (Electro.) }\end{array}$} & Graphite fiber brush & 7 & [110-116] \\
\hline & Carbon cloth & 7 & {$[15,117-122]$} \\
\hline & Carbon paper & 5 & [123-127] \\
\hline \multirow{3}{*}{$\begin{array}{l}\text { Reactor configuration } \\
\text { (Config.) }\end{array}$} & Single-chamber & 10 & {$[48,87,123,128-134]$} \\
\hline & Two-chamber & 9 & {$[20,52,122,135-140]$} \\
\hline & Large-scale & 7 & {$[49,56,141-145]$} \\
\hline
\end{tabular}

\subsection{Data Grouping and Processing}

The units of data (whichever applicable) reported in different studies were converted in order to be consistent and comparable. For example, the units " $\mathrm{mW} / \mathrm{m}^{2 "}$ (power per anode surface area) and " $\mathrm{m}^{3} \mathrm{H}^{2} / \mathrm{m}^{3} / \mathrm{d}$ " (hydrogen per reactor volume per day) were used for power density and hydrogen production rate, respectively. Due to the continuous nature of the reported data of temperature, $\mathrm{pH}$, and external resistance, data synthesis was performed for these factors to show the system responses to the changes of each factor, and to locate the range for the optimal performance (if applicable). For grouped data, such as substrate type, electrode material, and configuration, a meta-analysis was conducted for each factor to discuss the size of its effect.

For the meta-analysis, the Excel data file was exported to MetaWin (Version 2.1) for further processing. A categorical random effects model was used for the calculation of grouped effect sizes-i.e., a random effects model was used for groups of different categorical predictors, while a fixed effects model was used for those with negative estimated pooled variances [146]. All results with a $p$-value smaller than 0.05 were considered to be statistically significant. The calculated effect sizes were used to generate forest plots reflecting the impacts on the reactor performance. Each centered point stood for the mean effect size for each grouping, while the extended lines represented its $95 \%$ confidence interval (CI). Because the sets of data in this study were relatively small (mostly less than 30 ), the $t$-distribution (instead of the normal distribution) was utilized to construct the confidence interval following Equation (1).

$$
95 \% \mathrm{CI}=\bar{X} \pm t \frac{S}{\sqrt{N}}
$$

where $\bar{X}$ is the mean of the reported results; $S$ is the standard deviation; $N$ is the number of data inputs; and $t$ is the $t$-value, which measures the size of difference relative to the variation in the sample data. 


\subsection{Curve Fitting}

The experimental results were fitted using the nonlinear least squares regression, thus deriving the data for generating the fitted curves presented in Figures 2-4. The data were processed in MATLAB (R2018a, MathWorks, Natick, MA, USA).

\section{Conclusions}

The analysis of published data revealed the importance of operating temperature, $\mathrm{pH}$, external resistance, substrate, electrode material, and reactor configuration for the performance of MFCs and MECs. Domestic wastewater, in comparison with swine wastewater and landfill leachate, was the most suitable for these two BESs because of the higher power generation in MFCs, greater biohydrogen generation in MECs, and better treatment efficiency in terms of COD removal. The optimal temperature was found to be $25-35^{\circ} \mathrm{C}$, while optimal $\mathrm{pH}$ was $6-7$ and optimal external resistance was $100-1000 \Omega$. Although systems using carbon cloth as the electrodes demonstrated better performance, the high price of this material and other existing carbonaceous materials requires future investigations into novel materials that would be economic and porous. In order to scale up and commercialize MFCs and MECs, enhanced system performance and stability are needed, and could be possibly achieved with improved system designs.

Author Contributions: The authors equally contributed to the writing of this manuscript.

Funding: Hinkley Center for Solid and Hazardous Waste Management through grant number UF-EIES-0632020-FSU to Florida State University.

Acknowledgments: This work was supported by Hinkley Center for Solid and Hazardous Waste Management through grant number UF-EIES-0632020-FSU to Florida State University.

Conflicts of Interest: The authors declare no conflict of interest.

\section{References}

1. Bajracharya, S.; Srikanth, S.; Mohanakrishna, G.; Zacharia, R.; Strik, D.P.B.T.B.; Pant, D. Biotransformation of carbon dioxide in bioelectrochemical systems: State of the art and future prospects. J. Power Sources 2017, 356, 256-273. [CrossRef]

2. Wang, H.M.; Ren, Z.Y.J. A comprehensive review of microbial electrochemical systems as a platform technology. Biotechnol. Adv. 2013, 31, 1796-1807. [CrossRef] [PubMed]

3. Logan, B.E. Exoelectrogenic bacteria that power microbial fuel cells. Nat. Rev. Microbiol. 2009, 7, 375-381. [CrossRef] [PubMed]

4. Li, S.M.; Chen, G. Effects of evolving quality of landfill leachate on microbial fuel cell performance. Waste Manag. Res. 2018, 36, 59-67. [CrossRef] [PubMed]

5. Call, D.; Logan, B.E. Hydrogen production in a single chamber microbial electrolysis cell lacking a membrane. Environ. Sci. Technol. 2008, 42, 3401-3406. [CrossRef] [PubMed]

6. Sun, M.; Sheng, G.P.; Zhang, L.; Xia, C.R.; Mu, Z.X.; Liu, X.W.; Wang, H.L.; Yu, H.Q.; Qi, R.; Yu, T.; et al. An mec-mr-coupled system for biohydrogen production from acetate. Environ. Sci. Technol. 2008, 42, 8095-8100. [CrossRef] [PubMed]

7. Pandey, P.; Shinde, V.N.; Deopurkar, R.L.; Kale, S.P.; Patil, S.A.; Pant, D. Recent advances in the use of different substrates in microbial fuel cells toward wastewater treatment and simultaneous energy recovery. Appl. Energy 2016, 168, 706-723. [CrossRef]

8. Kumar, P.; Chandrasekhar, K.; Kumari, A.; Sathiyamoorthi, E.; Kim, B.S. Electro-fermentation in aid of bioenergy and biopolymers. Energies 2018, 11, 343. [CrossRef]

9. Min, B.; Logan, B.E. Continuous electricity generation from domestic wastewater and organic substrates in a flat plate microbial fuel cell. Environ. Sci. Technol. 2004, 38, 5809-5814. [CrossRef] [PubMed]

10. Ichihashi, O.; Hirooka, K. Removal and recovery of phosphorus as struvite from swine wastewater using microbial fuel cell. Bioresour. Technol. 2012, 114, 303-307. [CrossRef] [PubMed]

11. Feng, Y.; Wang, X.; Logan, B.E.; Lee, H. Brewery wastewater treatment using air-cathode microbial fuel cells. Appl. Microbiol. Biotechnol. 2008, 78, 873-880. [CrossRef] [PubMed] 
12. Ali, N.; Anam, M.; Yousaf, S.; Maleeha, S.; Bangash, Z. Characterization of the electric current generation potential of the pseudomonas aeruginosa using glucose, fructose, and sucrose in double chamber microbial fuel cell. Iran. J. Biotechnol. 2017, 15, 216-223. [CrossRef] [PubMed]

13. Cai, J.; Zheng, P.; Qaisar, M.; Sun, P. Effect of electrode types on simultaneous anaerobic sulfide and nitrate removal in microbial fuel cell. Sep. Purif. Technol. 2014, 134, 20-25. [CrossRef]

14. Yu, J.; Park, Y.; Lee, T. Effect of separator and inoculum type on electricity generation and microbial community in single-chamber microbial fuel cells. Bioprocess Biosyst. Eng. 2014, 37, 667-675. [CrossRef] [PubMed]

15. Liu, H.; Cheng, S.A.; Logan, B.E. Power generation in fed-batch microbial fuel cells as a function of ionic strength, temperature, and reactor configuration. Environ. Sci. Technol. 2005, 39, 5488-5493. [CrossRef] [PubMed]

16. Vicari, F.; Albamonte, M.; Galia, A.; Scialdone, O. Effect of mode of operation, substrate and final electron acceptor on single-chamber membraneless microbial fuel cell operating with a mixed community. J. Electroanal. Chem. 2018, 814, 104-110. [CrossRef]

17. Logan, B.E. Scaling up microbial fuel cells and other bioelectrochemical systems. Appl. Microbiol. Biotechnol. 2010, 85, 1665-1671. [CrossRef] [PubMed]

18. Tang, Y.L.; He, Y.T.; Yu, P.F.; Sun, H.; Fu, J.X. Effect of temperature on electricity generation of single-chamber microbial fuel cells with proton exchange membrane. Adv. Mater. Res. 2012, 393-395, 1169-1172. [CrossRef]

19. Behera, M.; Murthy, S.S.R.; Ghangrekar, M.M. Effect of operating temperature on performance of microbial fuel cell. Water Sci. Technol. 2011, 64, 917-922. [CrossRef] [PubMed]

20. Ahn, Y.; Logan, B.E. Effectiveness of domestic wastewater treatment using microbial fuel cells at ambient and mesophilic temperatures. Bioresour. Technol. 2010, 101, 469-475. [CrossRef] [PubMed]

21. Feng, Y.J.; Lee, H.; Wang, X.; Liu, Y.L. Electricity generation in microbial fuel cells at different temperature and isolation of electrogenic bacteria. In Proceedings of the 2009 Asia-Pacific Power and Energy Engineering Conference (APPEEC), Wuhan, China, 27-31 March 2009; Volumes 1-7, p. 530.

22. Trinh, N.T.; Park, J.H.; Kim, B.W. Increased generation of electricity in a microbial fuel cell using geobacter sulfurreducens. Korean J. Chem. Eng. 2009, 26, 748-753. [CrossRef]

23. Liu, Y.; Climent, V.; Berna, A.; Feliu, J.M. Effect of temperature on the catalytic ability of electrochemically active biofilm as anode catalyst in microbial fuel cells. Electroanalysis 2011, 23, 387-394. [CrossRef]

24. Heidrich, E.S.; Dolfing, J.; Wade, M.; Sloan, W.T.; Quince, C.; Curtis, T.P. Temperature, inocula and substrate: Contrasting electroactive consortia, diversity and performance in microbial fuel cells. Bioelectrochemistry 2018, 119, 43-50. [CrossRef] [PubMed]

25. Ahn, Y.; Im, S.; Chung, J.W. Optimizing the operating temperature for microbial electolysis cell treating sewage sludge. Int. J. Hydrogen Energy 2017, 42, 27784-27791. [CrossRef]

26. Gil, G.C.; Chang, I.S.; Kim, B.H.; Kim, M.; Jang, J.K.; Park, H.S.; Kim, H.J. Operational parameters affecting the performance of a mediator-less microbial fuel cell. Biosens. Bioelectron. 2003, 18, 327-334. [CrossRef]

27. Strik, D.P.B.T.B.; Picot, M.; Buisman, C.J.N.; Barriere, F. pH and temperature determine performance of oxygen reducing biocathodes. Electroanalysis 2013, 25, 652-655. [CrossRef]

28. Jia, Q.B.; Wei, L.L.; Han, H.L.; Shen, J.Q. Factors that influence the performance of two-chamber microbial fuel cell. Int. J. Hydrogen Energy 2014, 39, 13687-13693. [CrossRef]

29. Jannelli, N.; Nastro, R.A.; Cigolotti, V.; Minutillo, M.; Falcucci, G. Low pH, high salinity: Too much for microbial fuel cells? Appl. Energy 2017, 192, 543-550. [CrossRef]

30. Rismani-Yazdi, H.; Christy, A.D.; Carver, S.M.; Yu, Z.T.; Dehority, B.A.; Tuovinen, O.H. Effect of external resistance on bacterial diversity and metabolism in cellulose-fed microbial fuel cells. Bioresour. Technol. 2011, 102, 278-283. [CrossRef] [PubMed]

31. Jung, S.; Mench, M.M.; Regan, J.M. Impedance characteristics and polarization behavior of a microbial fuel cell in response to short-term changes in medium pH. Environ. Sci. Technol. 2011, 45, 9069-9074. [CrossRef] [PubMed]

32. Jung, S.; Regan, J.M. Influence of external resistance on electrogenesis, methanogenesis, and anode prokaryotic communities in microbial fuel cells. Appl. Environ. Microbiol. 2011, 77, 564-571. [CrossRef] [PubMed]

33. Pinto, R.P.; Srinivasan, B.; Guiot, S.R.; Tartakousky, B. The effect of real-time external resistance optimization on microbial fuel cell performance. Water Res. 2011, 45, 1571-1578. [CrossRef] [PubMed] 
34. Ding, W.J.; Cheng, S.A.; Yu, L.L.; Huang, H.B. Effective swine wastewater treatment by combining microbial fuel cells with flocculation. Chemosphere 2017, 182, 567-573. [CrossRef] [PubMed]

35. Hassan, M.; Wei, H.W.; Qiu, H.J.; Su, Y.L.; Jaafry, S.W.H.; Zhan, L.; Xie, B. Power generation and pollutants removal from landfill leachate in microbial fuel cell: Variation and influence of anodic microbiomes. Bioresour. Technol. 2018, 247, 434-442. [CrossRef] [PubMed]

36. Wei, J.C.; Liang, P.; Huang, X. Recent progress in electrodes for microbial fuel cells. Bioresour. Technol. 2011, 102, 9335-9344. [CrossRef] [PubMed]

37. Zhang, F.; Saito, T.; Cheng, S.A.; Hickner, M.A.; Logan, B.E. Microbial fuel cell cathodes with poly(dimethylsiloxane) diffusion layers constructed around stainless steel mesh current collectors. Environ. Sci. Technol. 2010, 44, 1490-1495. [CrossRef] [PubMed]

38. An, B.M.; Song, Y.H.; Shin, J.W.; Park, J.Y. Two-chamber microbial fuel cell to simultaneously remove ethanolamine and nitrate. Desalination Water Treat. 2016, 57, 7866-7873. [CrossRef]

39. Antonopoulou, G.; Stamatelatou, K.; Bebelis, S.; Lyberatos, G. Electricity generation from synthetic substrates and cheese whey using a two chamber microbial fuel cell. Biochem. Eng. J. 2010, 50, 10-15. [CrossRef]

40. Kim, J.R.; Cheng, S.; Oh, S.E.; Logan, B.E. Power generation using different cation, anion, and ultrafiltration membranes in microbial fuel cells. Environ. Sci. Technol. 2007, 41, 1004-1009. [CrossRef] [PubMed]

41. Lu, L.; Xing, D.F.; Xie, T.H.; Ren, N.Q.; Logan, B.E. Hydrogen production from proteins via electrohydrogenesis in microbial electrolysis cells. Biosens. Bioelectron. 2010, 25, 2690-2695. [CrossRef] [PubMed]

42. Zhang, F.; Ge, Z.; Grimaud, J.; Hurst, J.; He, Z. Long-term performance of liter-scale microbial fuel cells treating primary effluent installed in a municipal wastewater treatment facility. Environ. Sci. Technol. 2013, 47, 4941-4948. [CrossRef] [PubMed]

43. Asensio, Y.; Mansilla, E.; Fernandez-Marchante, C.M.; Lobato, J.; Canizares, P.; Rodrigo, M.A. Towards the scale-up of bioelectrogenic technology: Stacking microbial fuel cells to produce larger amounts of electricity. J. Appl. Electrochem. 2017, 47, 1115-1125. [CrossRef]

44. Hsu, L.; Chadwick, B.; Kagan, J.; Thacher, R.; Wotawa-Bergen, A.; Richter, K. Scale up considerations for sediment microbial fuel cells. RSC Adv. 2013, 3, 15947-15954. [CrossRef]

45. Rothstein, H.R.; Sutton, A.J.; Borenstein, M. Publication Bias in Meta-Analysis: Prevention, Assessment and Adjustments; Wiley: London, UK, 2005; pp. 1-7.

46. Asztalos, J.R.; Kim, Y. Enhanced digestion of waste activated sludge using microbial electrolysis cells at ambient temperature. Water Res. 2015, 87, 503-512. [CrossRef] [PubMed]

47. Catal, T.; Kavanagh, P.; O'Flaherty, V.; Leech, D. Generation of electricity in microbial fuel cells at sub-ambient temperatures. J. Power Sources 2011, 196, 2676-2681. [CrossRef]

48. Cheng, S.A.; Xing, D.F.; Logan, B.E. Electricity generation of single-chamber microbial fuel cells at low temperatures. Biosens. Bioelectron. 2011, 26, 1913-1917. [CrossRef] [PubMed]

49. Cotterill, S.E.; Dolfing, J.; Jones, C.; Curtis, T.P.; Heidrich, E.S. Low temperature domestic wastewater treatment in a microbial electrolysis cell with $1 \mathrm{~m}(2)$ anodes: Towards system scale-up. Fuel Cells 2017, 17, 584-592. [CrossRef]

50. Jadhav, G.S.; Ghangrekar, M.M. Performance of microbial fuel cell subjected to variation in $\mathrm{pH}$, temperature, external load and substrate concentration. Bioresour. Technol. 2009, 100, 717-723. [CrossRef] [PubMed]

51. Larrosa-Guerrero, A.; Scott, K.; Head, I.M.; Mateo, F.; Ginesta, A.; Hernandez-Fernandez, F.J.; Godinez, C. Low temperature performance of microbial fuel cells. In Proceedings of the PRES 2010: 13th International Conference on Process Integration, Modelling and Optimisation for Energy Saving and Pollution Reduction, Prague, Czech Republic, 28 August-1 September 2010; Volume 21, pp. 463-468.

52. Liu, L.H.; Tsyganova, O.; Lee, D.J.; Chang, J.S.; Wang, A.J.; Ren, N.Q. Double-chamber microbial fuel cells started up under room and low temperatures. Int. J. Hydrogen Energy 2013, 38, 15574-15579. [CrossRef]

53. Lu, L.; Xing, D.F.; Ren, N.Q.; Logan, B.E. Syntrophic interactions drive the hydrogen production from glucose at low temperature in microbial electrolysis cells. Bioresour. Technol. 2012, 124, 68-76. [CrossRef] [PubMed]

54. Ali, T.U.; Kim, M.; Kim, D.J. Selective inhibition of ammonia oxidation and nitrite oxidation linked to n2o emission with activated sludge and enriched nitrifiers. J. Microbiol. Biotechnol. 2013, 23, 719-723. [CrossRef] [PubMed] 
55. Barbato, R.A.; Foley, K.L.; Toro-Zapata, J.A.; Jones, R.M.; Reynolds, C.M. The power of soil microbes: Sustained power production in terrestrial microbial fuel cells under various temperature regimes. Appl. Soil Ecol. 2017, 109, 14-22. [CrossRef]

56. Cusick, R.D.; Bryan, B.; Parker, D.S.; Merrill, M.D.; Mehanna, M.; Kiely, P.D.; Liu, G.L.; Logan, B.E. Performance of a pilot-scale continuous flow microbial electrolysis cell fed winery wastewater. Appl. Microbiol. Biotechnol. 2011, 89, 2053-2063. [CrossRef] [PubMed]

57. Michie, I.S.; Kim, J.R.; Dinsdale, R.M.; Guwy, A.J.; Premier, G.C. The influence of psychrophilic and mesophilic start-up temperature on microbial fuel cell system performance. Energy Environ. Sci. 2011, 4, 1011-1019. [CrossRef]

58. Zhang, Y.P.; Sun, J.; Hu, Y.Y.; Wang, Z.Y.; Li, S.Z. Effects of periodically alternating temperatures on performance of single-chamber microbial fuel cells. Int. J. Hydrogen Energy 2014, 39, 8048-8054. [CrossRef]

59. Chae, K.J.; Choi, M.J.; Kim, K.Y.; Ajayi, F.F.; Chang, I.S.; Kim, I.S. Selective inhibition of methanogens for the improvement of biohydrogen production in microbial electrolysis cells. Int. J. Hydrogen Energy 2010, 35, 13379-13386. [CrossRef]

60. Omidi, H.; Sathasivan, A. Optimal temperature for microbes in an acetate fed microbial electrolysis cell (MEC). Int. Biodeterior. Biodegrad. 2013, 85, 688-692. [CrossRef]

61. Abbas, S.Z.; Rafatullah, M.; Ismail, N.; Nastro, R.A. Enhanced bioremediation of toxic metals and harvesting electricity through sediment microbial fuel cell. Int. J. Energy Res. 2017, 41, 2345-2355. [CrossRef]

62. Adelaja, O.; Keshavarz, T.; Kyazze, G. The effect of salinity, redox mediators and temperature on anaerobic biodegradation of petroleum hydrocarbons in microbial fuel cells. J. Hazard. Mater. 2015, 283, 211-217. [CrossRef] [PubMed]

63. Anam, M.; Yousaf, S.; Sharafat, I.; Zafar, Z.; Ayaz, K.; Ali, N. Comparing natural and artificially designed bacterial consortia as biosensing elements for rapid non-Specific detection of organic pollutant through microbial fuel cell. Int. J. Electrochem. Sci. 2017, 12, 2836-2851. [CrossRef]

64. Carver, S.M.; Vuoriranta, P.; Tuovinen, O.H. A thermophilic microbial fuel cell design. J. Power Sources 2011, 196, 3757-3760. [CrossRef]

65. Chen, Y.; Chen, M.; Shen, N.; Zeng, R.J. H-2 production by the thermoelectric microconverter coupled with microbial electrolysis cell. Int. J. Hydrogen Energy 2016, 41, 22760-22768. [CrossRef]

66. Hussain, A.; Mehta, P.; Raghavan, V.; Wang, H.; Guiot, S.R.; Tartakovsky, B. The performance of a thermophilic microbial fuel cell fed with synthesis gas. Enzyme Microb. Technol. 2012, 51, 163-170. [CrossRef] [PubMed]

67. Cerrillo, M.; Vinas, M.; Bonmati, A. Unravelling the active microbial community in a thermophilic anaerobic digester-microbial electrolysis cell coupled system under different conditions. Water Res. 2017, 110, 192-201. [CrossRef] [PubMed]

68. Ghasemi, M.; Daud, W.R.W.; Mokhtarian, N.; Mayahi, A.; Ismail, M.; Anisi, F.; Sedighi, M.; Alam, J. The effect of nitric acid, ethylenediamine, and diethanolamine modified polyaniline nanoparticles anode electrode in a microbial fuel cell. Int. J. Hydrogen Energy 2013, 38, 9525-9532. [CrossRef]

69. Huang, L.P.; Angelidaki, I. Effect of humic acids on electricity generation integrated with xylose degradation in microbial fuel cells. Biotechnol. Bioeng. 2008, 100, 413-422. [CrossRef] [PubMed]

70. Zhang, L.W.; Deshusses, M. Application of the finite difference method to model $\mathrm{pH}$ and substrate concentration in a double-chamber microbial fuel cell. Environ. Technol. 2014, 35, 1064-1076. [CrossRef] [PubMed]

71. Thung, W.E.; Ong, S.A.; Ho, L.N.; Wong, Y.S.; Ridwan, F.; Lehl, H.K.; Oon, Y.L.; Oon, Y.S. Biodegradation of acid orange 7 in a combined anaerobic-aerobic up-flow membrane-less microbial fuel cell: Mechanism of biodegradation and electron transfer. Chem. Eng. J. 2018, 336, 397-405. [CrossRef]

72. Ye, Y.J.; Wang, L.Y.; Chen, Y.W.; Zhu, S.M.; Shen, S.B. High yield hydrogen production in a single-chamber membrane-less microbial electrolysis cell. Water Sci. Technol. 2010, 61, 721-727. [CrossRef] [PubMed]

73. Li, J.T.; Zhang, S.H.; Hua, Y.M. Performance of denitrifying microbial fuel cell subjected to variation in $\mathrm{pH}$, cod concentration and external resistance. Water Sci. Technol. 2013, 68, 250-256. [CrossRef] [PubMed]

74. Tremouli, A.; Martinos, M.; Lyberatos, G. The effects of salinity, $\mathrm{pH}$ and temperature on the performance of a microbial fuel cell. Waste Biomass Valorization 2017, 8, 2037-2043. [CrossRef]

75. Feng, Y.L.; Cheng, Y.L.; Du, Y.L.; Teng, Q.; Li, H.R. Hydrogen production from acetate in a sleeve shape microbial electrolysis cell with a mipor cathode. Int. J. Electrochem. Sci. 2014, 9, 6993-7002. 
76. Montpart, N.; Rago, L.; Baeza, J.A.; Guisasola, A. Hydrogen production in single chamber microbial electrolysis cells with different complex substrates. Water Res. 2015, 68, 601-615. [CrossRef] [PubMed]

77. Raghavulu, S.V.; Mohan, S.V.; Goud, R.K.; Sarma, P.N. Effect of anodic pH microenvironment on microbial fuel cell (MFC) performance in concurrence with aerated and ferricyanide catholytes. Electrochem. Commun. 2009, 11, 371-375. [CrossRef]

78. Rozendal, R.A.; Hamelers, H.V.M.; Buisman, C.J.N. Effects of membrane cation transport on pH and microbial fuel cell performance. Environ. Sci. Technol. 2006, 40, 5206-5211. [CrossRef] [PubMed]

79. Puig, S.; Serra, M.; Coma, M.; Cabre, M.; Balaguer, M.D.; Colprim, J. Effect of pH on nutrient dynamics and electricity production using microbial fuel cells. Bioresour. Technol. 2010, 101, 9594-9599. [CrossRef] [PubMed]

80. Ajayi, F.F.; Kim, K.Y.; Chae, K.J.; Choi, M.J.; Kim, S.Y.; Chang, I.S.; Kim, I.S. Study of hydrogen production in light assisted microbial electrolysis cell operated with dye sensitized solar cell. Int. J. Hydrogen Energy 2009, 34, 9297-9304. [CrossRef]

81. Aelterman, P.; Versichele, M.; Marzorati, M.; Boon, N.; Verstraete, W. Loading rate and external resistance control the electricity generation of microbial fuel cells with different three-dimensional anodes. Bioresour. Technol. 2008, 99, 8895-8902. [CrossRef] [PubMed]

82. Cai, W.F.; Geng, J.F.; Pu, K.B.; Ma, Q.; Jing, D.W.; Wang, Y.H.; Chen, Q.Y.; Liu, H. Investigation of a two-dimensional model on microbial fuel cell with different biofilm porosities and external resistances. Chem. Eng. J. 2018, 333, 572-582. [CrossRef]

83. Katuri, K.P.; Scott, K.; Head, I.M.; Picioreanu, C.; Curtis, T.P. Microbial fuel cells meet with external resistance. Bioresour. Technol. 2011, 102, 2758-2766. [CrossRef] [PubMed]

84. Rago, L.; Monpart, N.; Cortes, P.; Baeza, J.A.; Guisasola, A. Performance of microbial electrolysis cells with bioanodes grown at different external resistances. Water Sci. Technol. 2016, 73, 1129-1135. [CrossRef] [PubMed]

85. Feng, Y.J.; Lee, H.; Wang, X.; Liu, Y.L.; He, W.H. Continuous electricity generation by a graphite granule baffled air-cathode microbial fuel cell. Bioresour. Technol. 2010, 101, 632-638. [CrossRef] [PubMed]

86. Coronado, J.; Perrier, M.; Tartakovsky, B. Pulse-width modulated external resistance increases the microbial fuel cell power output. Bioresour. Technol. 2013, 147, 65-70. [CrossRef] [PubMed]

87. Deng, H.; Wu, Y.C.; Zhang, F.; Huang, Z.C.; Chen, Z.; Xu, H.J.; Zhao, F. Factors affecting the performance of single-chamber soil microbial fuel cells for power generation. Pedosphere 2014, 24, 330-338. [CrossRef]

88. Huang, H.; Wang, X.H.; Gong, X.B.; You, S.J. Numerical anodic mass transfer of redox mediators in microbial fuel cell. In Proceedings of the 2013 International Conference on Materials for Renewable Energy and Environment (ICMREE), Chengdu, China, 19-21 August 2014; IEEE: Piscataway, NJ, USA, 2013; Volumes 1-3, pp. 298-302.

89. Sukkasem, C.; Xua, S.T.; Park, S.; Boonsawang, P.; Liu, H. Effect of nitrate on the performance of single chamber air cathode microbial fuel cells. Water Res. 2008, 42, 4743-4750. [CrossRef] [PubMed]

90. Sun, M.; Sheng, G.P.; Mu, Z.X.; Liu, X.W.; Chen, Y.Z.; Wang, H.L.; Yu, H.Q. Manipulating the hydrogen production from acetate in a microbial electrolysis cell-microbial fuel cell-coupled system. J. Power Sources 2009, 191, 338-343. [CrossRef]

91. Yan, H.J.; Yates, M.D.; Regan, J.M. Effects of constant or dynamic low anode potentials on microbial community development in bioelectrochemical systems. Appl. Microbiol. Biotechnol. 2015, 99, 9319-9329. [CrossRef] [PubMed]

92. Brown, R.K.; Harnisch, F.; Dockhorn, T.; Schroder, U. Examining sludge production in bioelectrochemical systems treating domestic wastewater. Bioresour. Technol. 2015, 198, 913-917. [CrossRef] [PubMed]

93. Kim, K.Y.; Yang, W.L.; Logan, B.E. Impact of electrode configurations on retention time and domestic wastewater treatment efficiency using microbial fuel cells. Water Res. 2015, 80, 41-46. [CrossRef] [PubMed]

94. Stager, J.L.; Zhang, X.Y.; Logan, B.E. Addition of acetate improves stability of power generation using microbial fuel cells treating domestic wastewater. Bioelectrochemistry 2017, 118, 154-160. [CrossRef] [PubMed]

95. You, S.J.; Zhao, Q.L.; Jiang, J.Q.; Zhang, J.N. Treatment of domestic wastewater with simultaneous electricity generation in microbial fuel cell under continuous operation. Chem. Biochem. Eng. Q. 2006, 20, 407-412.

96. Zawawi, M.H.; Mimit, M.N.; Rosli, N.A.; Hossain, M.D.; Zainal, N.A.; Kamarudin, M.A. Efficiency of single chamber microbial fuel cell (MFC) in wastewater treatment. Int. J. Adv. Appl. Sci. 2017, 4, 47-51. [CrossRef] 
97. Heidrich, E.S.; Edwards, S.R.; Dolfing, J.; Cotterill, S.E.; Curtis, T.P. Performance of a pilot scale microbial electrolysis cell fed on domestic wastewater at ambient temperatures for a 12 month period. Bioresour. Technol. 2014, 173, 87-95. [CrossRef] [PubMed]

98. Angosto, J.M.; Fernandez-Lopez, J.A.; Godinez, C. Brewery and liquid manure wastewaters as potential feedstocks for microbial fuel cells: A performance study. Environ. Technol. 2015, 36, 68-78. [CrossRef] [PubMed]

99. Egbadon, E.O.; Akujobi, C.O.; Nweke, C.O.; Braide, W.; Akaluka, C.K.; Adeleye, S.A. Simultaneous generation of bioelectricity and treatment of swine wastewater in a microbial fuel cell. Int. Lett. Nat. Sci. 2016, 54, 100-107. [CrossRef]

100. Lin, H.J.; Wu, X.; Nelson, C.; Miller, C.; Zhu, J. Electricity generation and nutrients removal from high-strength liquid manure by air-cathode microbial fuel cells. J. Environ. Sci. Health Part A 2016, 51, 240-250. [CrossRef] [PubMed]

101. Ogugbue, C.J.; Ebode, E.E.; Leera, S. Electricity generation from swine wastewater using microbial fuel cell. J. Ecol. Eng. 2015, 16, 26-33. [CrossRef]

102. Min, B.; Kim, J.R.; Oh, S.E.; Regan, J.M.; Logan, B.E. Electricity generation from swine wastewater using microbial fuel cells. Water Res. 2005, 39, 4961-4968. [CrossRef] [PubMed]

103. Cetinkaya, A.Y.; Ozkaya, B.; Taskan, E.; Karadag, D.; Cakmakci, M. The production of electricity from dual-chambered microbial fuel cell fueled by old age leachate. Energy Source Part A 2016, 38, 1544-1552. [CrossRef]

104. Greenman, J.; Galvez, A.; Giusti, L.; Ieropoulos, L. Electricity from landfill leachate using microbial fuel cells: Comparison with a biological aerated filter. Enzyme Microb. Technol. 2009, 44, 112-119. [CrossRef]

105. Hassan, M.; Pous, N.; Xie, B.; Colprim, J.; Balaguer, M.D.; Puig, S. Influence of iron species on integrated microbial fuel cell and electro-fenton process treating landfill leachate. Chem. Eng. J. 2017, 328, 57-65. [CrossRef]

106. Rikame, S.S.; Mungray, A.A.; Mungray, A.K. Electricity generation from acidogenic food waste leachate using dual chamber mediator less microbial fuel cell. Int. Biodeterior. Biodegrad. 2012, 75, 131-137. [CrossRef]

107. Yuan, H.R.; Deng, L.F.; Chen, Y. Optimization of biodrying pretreatment of municipal solid waste and microbial fuel cell treatment of leachate. Biotechnol. Bioproc. Eng. 2014, 19, 668-675. [CrossRef]

108. Huang, L.; Li, X.C.; Cai, T.; Huang, M.H. Electrochemical performance and community structure in three microbial fuel cells treating landfill leachate. Process Saf. Environ. Protect. 2018, 113, 378-387. [CrossRef]

109. Shehzad, A.; Bashir, M.J.K.; Sethupathi, S.; Lim, J.W.; Younas, M. Bioelectrochemical system for landfill leachate treatment-Challenges, opportunities, and recommendations. Geosyst. Eng. 2016, 19, 337-345. [CrossRef]

110. Ahn, Y.T.; Logan, B.E. Altering anode thickness to improve power production in microbial fuel cells with different electrode distances. Energy Fuel 2013, 27, 271-276. [CrossRef]

111. Chen, S.L.; Patil, S.A.; Schroder, U. A high-performance rotating graphite fiber brush air-cathode for microbial fuel cells. Appl. Energy 2018, 211, 1089-1094. [CrossRef]

112. Hutchinson, A.J.; Tokash, J.C.; Logan, B.E. Analysis of carbon fiber brush loading in anodes on startup and performance of microbial fuel cells. J. Power Sources 2011, 196, 9213-9219. [CrossRef]

113. Wagner, R.C.; Regan, J.M.; Oh, S.E.; Zuo, Y.; Logan, B.E. Hydrogen and methane production from swine wastewater using microbial electrolysis cells. Water Res. 2009, 43, 1480-1488. [CrossRef] [PubMed]

114. Zhang, G.D.; Zhao, Q.L.; Jiao, Y.; Zhang, J.N.; Jiang, J.Q.; Ren, N.; Kim, B.H. Improved performance of microbial fuel cell using combination biocathode of graphite fiber brush and graphite granules. J. Power Sources 2011, 196, 6036-6041. [CrossRef]

115. Nam, T.; Son, S.; Koo, B.; Tran, H.V.H.; Kim, J.R.; Choi, Y.; Jung, S.P. Comparative evaluation of performance and electrochemistry of microbial fuel cells with different anode structures and materials. Int. J. Hydrogen Energy 2017, 42, 27677-27684. [CrossRef]

116. Zhen, G.Y.; Lu, X.Q.; Kumar, G.; Bakonyi, P.; Xu, K.Q.; Zhao, Y.C. Microbial electrolysis cell platform for simultaneous waste biorefinery and clean electrofuels generation: Current, situation, challenges and future perspectives. Prog. Energy Combust. Sci. 2017, 63, 119-145. [CrossRef]

117. Aelterman, P.; Versichele, M.; Genettello, E.; Verbeken, K.; Verstraete, W. Microbial fuel cells operated with iron-chelated air cathodes. Electrochim. Acta 2009, 54, 5754-5760. [CrossRef] 
118. Butler, C.S.; Nerenberg, R. Performance and microbial ecology of air-cathode microbial fuel cells with layered electrode assemblies. Appl. Microbiol. Biotechnol. 2010, 86, 1399-1408. [CrossRef] [PubMed]

119. Chen, Y.M.; Wang, C.T.; Yang, Y.C.; Chen, W.J. Application of aluminum-alloy mesh composite carbon cloth for the design of anode/cathode electrodes in escherichia coli microbial fuel cell. Int. J. Hydrogen Energy 2013, 38, 11131-11137. [CrossRef]

120. Tsan, W.C.; Jung, C.W.; Yao, H.R. Effect of culture time on the growth curve and power performance in a microbial fuel cell at a fixed amount of liquid culture. Int. J. Green Energy 2016, 13, 695-702. [CrossRef]

121. Cai, W.F.; Geng, D.L.; Wang, Y.H. Assessment of cathode materials for Ni(ii) reduction in microbial electrolysis cells. RSC Adv. 2016, 6, 31732-31738. [CrossRef]

122. Zhang, J.; Li, J.; Ye, D.D.; Zhu, X.; Liao, Q.; Zhang, B.A. Enhanced performances of microbial fuel cells using surface-modified carbon cloth anodes: A comparative study. Int. J. Hydrogen Energy 2014, 39, 19148-19155. [CrossRef]

123. Amade, R.; Moreno, H.A.; Hussain, S.; Vila-Costa, M.; Bertran, E. Vertically aligned carbon nanotubes as anode and air-cathode in single chamber microbial fuel cells. Appl. Phys. Lett. 2016, 109. [CrossRef]

124. Chen, Y.W.; Xu, Y.; Chen, L.L.; Li, P.W.; Zhu, S.M.; Shen, S.B. Microbial electrolysis cells with polyaniline/multi-walled carbon nanotube-modified biocathodes. Energy 2015, 88, 377-384. [CrossRef]

125. Erbay, C.; Yang, G.; de Figueiredo, P.; Sadr, R.; Yu, C.H.; Han, A. Three-dimensional porous carbon nanotube sponges for high-performance anodes of microbial fuel cells. J. Power Sources 2015, 298, 177-183. [CrossRef]

126. Wang, L.Y.; Chen, Y.W.; Huang, Q.; Feng, Y.Y.; Zhu, S.M.; Shen, S.B. Hydrogen production with carbon nanotubes based cathode catalysts in microbial electrolysis cells. J. Chem. Technol. Biotechnol. 2012, 87, 1150-1156. [CrossRef]

127. Ghasemi, M.; Daud, W.R.W.; Hassan, S.H.A.; Jafary, T.; Rahimnejad, M.; Ahmad, A.; Yazdi, M.H. Carbon nanotube/polypyrrole nanocomposite as a novel cathode catalyst and proper alternative for Pt in microbial fuel cell. Int. J. Hydrogen Energy 2016, 41, 4872-4878. [CrossRef]

128. Bo, T.; Zhu, X.Y.; Zhang, L.X.; Tao, Y.; He, X.H.; Li, D.P.; Yan, Z.Y. A new upgraded biogas production process: Coupling microbial electrolysis cell and anaerobic digestion in single-chamber, barrel-shape stainless steel reactor. Electrochem. Commun. 2014, 45, 67-70. [CrossRef]

129. Hu, H.Q.; Fan, Y.Z.; Liu, H. Hydrogen production using single-chamber membrane-free microbial electrolysis cells. Water Res. 2008, 42, 4172-4178. [CrossRef] [PubMed]

130. Wu, T.T.; Zhu, G.F.; Jha, A.K.; Zou, R.; Liu, L.; Huang, X.; Liu, C.X. Hydrogen production with effluent from an anaerobic baffled reactor (ABR) using a single-chamber microbial electrolysis cell (MEC). Int. J. Hydrogen Energy 2013, 38, 11117-11123. [CrossRef]

131. Cui, K.P.; Wang, Y.; Sun, S.Q. Electricity generation and wastewater treatment using an air-cathode single chamber microbial fuel cell. In Proceedings of the 2010 Asia-Pacific Power and Energy Engineering Conference (APPEEC), Chengdu, China, 28-31 March 2010.

132. Kim, H.; Kim, B.; Kim, J.; Lee, T.; Yu, J. Electricity generation and microbial community in microbial fuel cell using low-pH distillery wastewater at different external resistances. J. Biotechnol. 2014, 186, 175-180. [CrossRef] [PubMed]

133. Abourached, C.; Catal, T.; Liu, H. Efficacy of single-chamber microbial fuel cells for removal of cadmium and zinc with simultaneous electricity production. Water Res. 2014, 51, 228-233. [CrossRef] [PubMed]

134. Lu, L.; Ren, N.Q.; Zhao, X.; Wang, H.A.; Wu, D.; Xing, D.F. Hydrogen production, methanogen inhibition and microbial community structures in psychrophilic single-chamber microbial electrolysis cells. Energy Environ. Sci. 2011, 4, 1329-1336. [CrossRef]

135. Chae, K.J.; Choi, M.J.; Lee, J.; Ajayi, F.F.; Kim, I.S. Biohydrogen production via biocatalyzed electrolysis in acetate-fed bioelectrochemical cells and microbial community analysis. Int. J. Hydrogen Energy 2008, 33, 5184-5192. [CrossRef]

136. Kyazze, G.; Popov, A.; Dinsdale, R.; Esteves, S.; Hawkes, F.; Premier, G.; Guwy, A. Influence of catholyte $\mathrm{pH}$ and temperature on hydrogen production from acetate using a two chamber concentric tubular microbial electrolysis cell. Int. J. Hydrogen Energy 2010, 35, 7716-7722. [CrossRef]

137. Nam, J.Y.; Logan, B.E. Optimization of catholyte concentration and anolyte pHs in two chamber microbial electrolysis cells. Int. J. Hydrogen Energy 2012, 37, 18622-18628. [CrossRef]

138. Rivera, I.; Buitron, G.; Bakonyi, P.; Nemestothy, N.; Belafi-Bako, K. Hydrogen production in a microbial electrolysis cell fed with a dark fermentation effluent. J. Appl. Electrochem. 2015, 45, 1223-1229. [CrossRef] 
139. Esfandyari, M.; Fanaei, M.A.; Gheshlaghi, R.; Mandavi, M.A. Dynamic modeling of a continuous two-chamber microbial fuel cell with pure culture of shewanella. Int. J. Hydrogen Energy 2017, 42, 21198-21202. [CrossRef]

140. Xiao, B.Y.; Yang, F.; Liu, J.X. Evaluation of electricity production from alkaline pretreated sludge using two-chamber microbial fuel cell. J. Hazard. Mater. 2013, 254, 57-63. [CrossRef] [PubMed]

141. Escapa, A.; Mateos, R.; Martinez, E.J.; Blanes, J. Microbial electrolysis cells: An emerging technology for wastewater treatment and energy recovery. From laboratory to pilot plant and beyond. Renew. Sustain. Energy Rev. 2016, 55, 942-956. [CrossRef]

142. Kadier, A.; Logrono, W.; Rai, P.K.; Kalil, M.S.; Mohamed, A.; Abu Hasan, H.; Hamid, A.A. None-platinum electrode catalysts and membranes for highly efficient and inexpensive h-2 production in microbial electrolysis cells (MECS): A review. Iran. J. Catal. 2017, 7, 89-102.

143. Heidrich, E.S.; Dolfing, J.; Scott, K.; Edwards, S.R.; Jones, C.; Curtis, T.P. Production of hydrogen from domestic wastewater in a pilot-scale microbial electrolysis cell. Appl. Microbiol. Biotechnol. 2013, 97, 6979-6989. [CrossRef] [PubMed]

144. Jiang, Y.; Liang, P.; Zhang, C.Y.; Bian, Y.H.; Sun, X.L.; Zhang, H.L.; Yang, X.F.; Zhao, F.; Huang, X. Periodic polarity reversal for stabilizing the $\mathrm{pH}$ in two-chamber microbial electrolysis cells. Appl. Energy 2016, 165, 670-675. [CrossRef]

145. Jiang, D.Q.; Curtis, M.; Troop, E.; Scheible, K.; McGrath, J.; Hu, B.X.; Suib, S.; Raymond, D.; Li, B.K. A pilot-scale study on utilizing multi-anode/cathode microbial fuel cells (MAC MFCS) to enhance the power production in wastewater treatment. Int. J. Hydrogen Energy 2011, 36, 876-884. [CrossRef]

146. Jeffery, S.; Verheijen, F.G.A.; van der Velde, M.; Bastos, A.C. A quantitative review of the effects of biochar application to soils on crop productivity using meta-analysis. Agric. Ecosyst. Environ. 2011, 144, 175-187. [CrossRef]

(C) 2018 by the authors. Licensee MDPI, Basel, Switzerland. This article is an open access article distributed under the terms and conditions of the Creative Commons Attribution (CC BY) license (http:/ / creativecommons.org/licenses/by/4.0/). 